\title{
Agnieszka Woynarowska
}

Uniwersytet Gdański

\section{Aktywiści z niepełnosprawnością w walce o niezależne życie, równe szanse i prawa człowieka. O sile protestów, opresji władzy i społecznym oporze}

Artykuł prezentuje działalność ruchów społecznych środowisk osób niepełnosprawnych i aktywistów z niepełnosprawnością, walczących o możliwość prowadzenia niezależnego życia, o równe szanse i prawa człowieka. Autorka w kontekście teorii ruchów społecznych, nieposłuszeństwa obywatelskiego i samoorganizacji osób niepełnosprawnych ukazuje ową walkę w pryzmacie dwóch protestów osób z niepełnosprawnościami i ich rodziców, które miały miejsce w 2014 i 2018 roku w Sejmie RP.

Słowa kluczowe: aktywizm osób z niepełnosprawnością, ruchy społeczne osób niepełnosprawnych, walka o niezależne życie i prawa człowieka

\section{Disability activists in the struggle for independent lives, equal opportunities and human rights. On the power of the protests, the government's oppression and social defiance}

The article presents the activities of disability rights movement and activists with disabilities fighting for the possibility of leading an independent life, for equal opportunities and human rights. In the context of the theory of social movements, civil disobedience and self-organization of people with disabilities, the author shows this fight in the prism of two protests of people with disabilities and their parents that took place in 2014 and 2018 in the Polish Parliament.

Keywords: activism of people with disabilities, , disability rights movement, the struggle for independent life and human rights

\section{Wprowadzenie}

W 1994 roku wydano pierwszy numer magazynu Integracja. Jego pomysłodawcami byli Piotr Pawłowski i Bolesław Bryński. W 1995 roku powstaje Stowarzyszenie Przyjaciół Integracji, którego prezesem zostaje Piotr Pawłowski. Misją Integra- 
cji była poprawa sytuacji osób z niepełnosprawnością, kształtowanie świadomości obywatelskiej, działanie na rzecz wyrównywania szans oraz integracji społecznej. Marzeniem Piotra Pawłowskiego było uczynienie Polski krajem wolnym od barier oraz negatywnych stereotypów związanych z osobami niepełnosprawnymi. Ta zainicjowana w latach 90. XX wieku działalność Piotra Pawłowskiego oraz Stowarzyszenia Przyjaciół Integracji zapoczątkowała aktywizm osób niepełnosprawnych w Polsce oraz ich politykę emancypacji. Przemiany ustrojowe wczesnych lat 90. dawały obietnicę nowego, demokratycznego, pluralistycznego porządku i nadzieję na zniesienie dotychczasowych barier. Dzięki rodzącej się demokracji do głosu dopuszczonych zostało wiele grup mniejszościowych, które do tej pory były tego głosu pozbawiane. Nastał czas ponowoczesnego otwarcia na różnicę. Środowiska osób z niepełnosprawnością coraz bardziej świadome swoich praw zaczęly w przestrzeni publicznej i politycznej głośno o nich mówić. Spopularyzowane w latach 90. przez Jamesa Charltona i Davida Wernera hasło "Nic o nas bez nas", stało się również hasłem polskich aktywistów z niepełnosprawnością. W tym haśle zawierają się najważniejsze postulaty aktywistów z niepełnosprawnością - walka o godność i podmiotowość, uznanie za pełnoprawnych obywateli, uczestników życia społecznego, za obywateli posiadających te same prawa, które przysługują sprawnym członkom naszego społeczeństwa. Hasło „Nic o nas bez nas" to początek polityki wyzwolenia, walki o prawa obywatelskie, niezależne życie oraz początek zwiększenia aktywności politycznej osób z niepełnosprawnościami. Ratyfikowana przez Polskę w 2012 roku Konwencja Praw Osób Niepełnosprawnych ONZ stała się kolejnym orężem w walce o równe szanse i emancypację.

Samoorganizacja środowisk osób niepełnosprawnych przybrała w Polsce kształt organizacji pozarządowych działających na rzecz osób niepełnosprawnych zarówno na szczeblu lokalnym, jak i ogólnopolskim. Niepełnosprawność jest pojęciem bardzo ogólnym. Osoby niepełnosprawne to bardzo zróżnicowana grupa osób, o bardzo różnych potrzebach. Częścią wspólną tożsamości osób niepełnosprawnych może być ich tożsamość polityczna i siła wynikająca $\mathrm{z}$ bezpośredniego wspólnego działania. T. Shakespeare definiuje tożsamość - w sensie politycznym - jako przynależność do grupy uciskanej, do kulturowej mniejszości (Shakespeare 2018: 39). Utożsamianie się z grupą uciskaną powoduje wspólne zorganizowanie się $\mathrm{w}$ celu dokonania zmian społecznych. Wielu aktywistów z niepełnosprawnością, aktywistów dla niepełnosprawności - rodziców, terapeutów czy nauczycieli działa $\mathrm{w}$ obszarze organizacji pozarządowych skupionych wokół konkretnej niepełnosprawności. Walcząc o swoje prawa prowadzą działalność ekspercką i doradczą, budują lokalny system wsparcia i mają wpływ na kształtowanie polityki społecznej na rzecz osób z daną niepełnosprawnością. I tak, Koalicja Autyzm Polska od lat walczy o poprawę sytuacji osób z autyzmem w Pol- 
sce o stworzenie prawa uwzględniającego potrzebę tej grupy osób, Koalicja 21 z kolei walczy o lepsze możliwości realizacji idei niezależnego życia dla osób z Zespołem Downa. Dla Polskiego Związku Głuchych istotne są kwestie praw osób niesłyszących. Wszystkie te środowiska łączy ich wspólna polityczna tożsamość przynależność do mniejszości kulturowej, do grupy społecznie uciskanej. Sytuację samoorganizacji osób niepełnosprawnych w Polsce można podsumować konstatacją Olivera i Barnesa, którzy uznają, że rozwój samoorganizacji doprowadził do tego, że coraz więcej osób niepełnosprawnych przyjmuje wspólną polityczną tożsamość, co z kolei daje im pewność siebie. Osoby niepełnosprawne już nie proszą o zmiany, lecz żądają ich. Dążąc do realizacji postulatów, są gotowe sięgnąć po całą gamę środków, łącznie z bezpośrednim działaniem i obywatelskim nieposłuszeństwem (Bynoe, Oliver, Barnes 1991: 12, za: Shakespeare 2018: 37).

Przez wiele lat aktywiści z niepełnosprawnością, rodzice osób niepełnosprawnych, środowiska osób niepełnosprawnych poprzez pracę doradczą i ekspercką, poprzez postulaty i prośby, pracę z władzami samorządowymi i rządem polskim próbowali zmieniać politykę społeczną, implementować idee równości i inkluzji, budować system wsparcia, z bardzo różnym skutkiem. W poczuciu bezsilności w 2014 roku rodzice osób niepełnosprawnych, rozpoczęli pierwszy strajk okupacyjny w Sejmie RP. W 2018 roku miał miejsce drugi strajk okupacyjny RON (Rodzice Osób Niepełnosprawnych) w Sejmie RP, największy i najdłuższy w dziejach współczesnej Polski. Czy mamy zatem do czynienia z powstaniem Ruchu Społecznego Osób Niepełnosprawnych, gdzie niepełnosprawni stali się zwartą siła polityczną, a feministyczne hasło "osobiste jest polityczne”, stało się również ich hasłem? W dalszej analizie aktywizmu osób niepełnosprawnych koncentruję się na wyeksponowaniu owych dwóch protestów rodziców osób niepełnosprawnych, a szczególnie dyskursywnych praktyk, poprzez które oba protesty były realizowane.

\section{Ruchy społeczne osób niepełnosprawnych i ich obywatelskie nieposłuszeństwo}

Ruch społeczny to forma spontanicznego działania pewnych kategorii zbiorowości, zmierzającego do określonego celu i często do wywołania zmiany społecznej. Ruch społeczny może przyczyniać się do zmiany społecznej lub być przez nią wywołany, może zmierzać do wprowadzenia zmian lub do ich hamowania, może dążyć do wprowadzenia zmian szybko, za jednym zamachem, bądź działać na rzecz stopniowego, powolnego ich wprowadzenia. Ruchy społeczne nie tworzą skomplikowanych struktur organizacyjnych, jednakże w sytuacji, gdy mają moż- 
liwość wpływu na władzę i mogą nie tylko postulatywnie głosić potrzebę zmiany, lecz także zmianę tę wprowadzać, wówczas następuje ich instytucjonalizacja, przy czym same przekształcają się w organizacje (Sztompka 2005). Giddens natomiast zauważa, że najczęściej nieortodoksyjna działalność polityczna przybiera postać ruchów społecznych- zbiorowych akcji, mających na celu forsowanie zbiorowych interesów lub dążenie do wspólnego celu, prowadzonych poza sferą ustanowionych instytucji (Giddens 2005: 463). Niektóre ruchy społeczne istnieją tylko przejściowo, inne są bardziej trwałe, niektóre są małe i liczą nie więcej niż kilkudziesięciu członków, liczebność innych jest znacznie większa (Giddens, 2005:463). Działalność tych grup protestu najczęściej rozgrywa się na granicy tego, co w danym czasie i miejscu uznaje się za dopuszczalne z punktu widzenia prawa (tamże: 463).

Celem ruchów społecznych jest najczęściej przeprowadzenie zmian dotyczących określonej kwestii publicznej. Ruchom społecznym często udaje się doprowadzić do zmian w prawodawstwie i polityce. Skutki tych zmian mogą być dalekosiężne. Ruchy społeczne należą do najpotężniejszych form działalności zbiorowej. Dobrze zorganizowane i wytrwale prowadzone kampanie mogą przynosić spektakularne efekty. Od lat 70. XX w. ruchy społeczne bardzo rozpowszechniły się na całym świecie. Wszystkie one zarówno te na rzecz praw obywatelskich, ruchów feministycznych, ruchu LGBT czy ruchu praw osób niepełnosprawnych, często, jak pisze Giddens, określa się wspólną nazwą - nowych ruchów społecznych (Giddens 2005: 464). Uważa on, że nowe ruchy społeczne można postrzegać w kategoriach „paradoksu demokracji”. Podczas gdy z jednej strony zaufanie do tradycyjnej polityki zdaje się słabnąć, z drugiej strony rozwój nowych ruchów społecznych dowodzi, że wbrew temu, co się niekiedy mówi, obywatele późnonowoczesnych społeczeństw nie są apatyczni i interesują się polityką. Panuje przekonanie, że bezpośrednia akcja przynosi lepsze skutki niż odwoływanie się do polityków. Ludzie bardziej niż kiedykolwiek popierają działalność ruchów społecznych jako sposobu nagłaśniania skomplikowanych kwestii moralnych i stawiania ich w centrum życia społecznego (Giddens 2005: 465).

Według A. Scott, ruch społeczny jest zbiorowym aktorem, stworzonym przez jednostki, które sądzą, że łączą je wspólne interesy i wspólna tożsamość. Tym, co odróżnia ruchy społeczne od innych aktorów zbiorowych, takie jak partie społeczne i grupy nacisku, jest odwołanie do masowej mobilizacji lub jej groźba. Masowa mobilizacja jest podstawowym źródłem sankcji społecznej i w niej tkwi siła ruchu (Scott 1990: 9, za: Shakespeare 2018: 43).

Na świecie, od wielu lat, Ruchy Społeczne Osób Niepełnosprawnych Disability Rights Movements walczą o równość, politykę włączenia i zmianę sytuacji społeczno-politycznej osób z niepełnosprawnościami. Do hasła "Nic o nas bez nas” dołącza hasło „Piss On Pity”. To okrzyk aktywistów, którzy uznają, że litość, choć wydaje 
się być pozytywną emocją, w rzeczywistości jest uwłaczająca. Według nich opiera się ona na świadomej lub nieświadomej niechęci do osób niepełnosprawnych. Okrzyk ten ma promować politykę równości. Jedną z cech ruchu społecznego osób niepełnosprawnych, jak zauważa Shakespeare, jest również wyeksponowanie ukrytych opresyjnych ideologii i relacji społecznych, i obnażenie, że to, co wydawało się altruistyczną życzliwością, jest wyeksponowane jako paternalistyczna dominacja (Shakespeare, 2018: 50).

Nieposłuszeństwo obywatelskie niepełnosprawnych obywateli i walka ruchów osób niepełnosprawnych doprowadziła do wielu społecznych zmian, w wielu krajach. Warto wspomnieć o działaniach brytyjskiego Związku Upośledzonych Przeciwko Segregacji (UPIAS), które to doprowadziły do rozwoju społecznego modelu niepełnosprawności, w którym dokonuje się wyraźnego rozróżnienia między uszkodzeniem a niepełnosprawnością. W USA ruch na rzecz praw osób niepełnosprawnych rozpoczął się $\mathrm{w}$ latach 60 . XX wieku, wspierany przez przykłady ruchu na rzecz praw obywatelskich i praw kobiet. Jednym z najistotniejszych wydarzeń była okupacja w latach 70 . XX w. wielu budynków rządowych, zorganizowana przez Amerykańską Koalicję Obywateli Niepełnosprawnych, co doprowadziło do wydania przepisów zgodnie z Sekcją 504 Ustawy o Rehabilitacji z 1973 roku. Protest ten był znaczący nie tylko dlatego, że jego cel został osiągnięty, ale także dlatego, że był to przede wszystkim wspólny wysiłek osób o różnym stopniu niepełnosprawności, które spotykały się w celu wsparcia ustawodawstwa.

Większość ruchów społecznych osób niepełnosprawnych, aby zrealizować swoje postulaty, wkracza na polityczną arenę posuwając się do obywatelskiego nieposłuszeństwa. T. Shakespeare zwraca uwagę, że grupy spoza systemu pozostające w sytuacji „pluralizmu resztek”, sfrustrowane niemożnością zwrócenia uwagi decydentów politycznych na swoje problemy, uciekają się do metod niekonwencjonalnych, takich jak bojkot, demonstracje, strajki również okupacyjne. Celem jest zwrócenie uwagi opinii publicznej i decydentów (Shakespeare 2018: 48). To działanie jest $w$ pełni uzasadnione, gdyż nieposłuszeństwo obywatelskie jest instrumentem, który - przy uwzględnieniu wszystkich jego ograniczeń, może być wykorzystywane $\mathrm{w}$ państwach o ustroju demokratycznym jako gwarant ochrony praw obywatelskich przed działaniem władzy, zmierzającej w kierunku naruszenia tych praw (Stoczewska 2017: 83-84).

M. Bogaczyk-Vormayr, analizując koncepcję nieposłuszeństwa obywatelskiego H. Arendt, zauważa, że nieposłuszeństwo obywatelskie jest pewną utrwaloną formułą społeczno-polityczną, będącą wyrazem "politycznego faktu wielości” (Bogaczyk-Vormayr 2013: 224). Wg H. Arendt, polityczność przenika życie społeczne, gdyż „polityka za swą podstawę ma fakt ludzkiej wielości” (Arendt 2005: 124). Fakt wielości, jak pisze Bogaczyk-Vormayr, analizując koncepcję 
Arendt, podpowiada nam jednak konieczność dwojakiej wykładni samego terminu "obywatelskie nieposłuszeństwo": jest ono konkretną wypowiedzią/aktem wobec innej, zastanej wypowiedzi, przez co staje się tym, co wytwarza lub rozszerza wielość. Jest ono wypowiedzią grupy albo jednostki (jakiegoś podmiotu), mającą za cel zamanifestowanie a następnie wytworzenie pewnej jedności - np. w postaci nowego, powszechnie obowiązującego, prawa. Nieposłuszeństwo obywatelskie jest zatem aktem opartym na fenomenie wzajemności, definiującym jednostkę jako współobywatela, jednoczącym aktorów życia społecznego siłą ich wzajemnych powiązań (Bogaczyk- Vormayr 2013: 224).

\section{Szkic metodologiczny}

Analizując polski aktywizm osób z niepełnosprawnoscią chciałabym skoncentrować się na wydarzeniach, które miały miejsce w Sejmie RP w 2014 i 2018 roku i były najbardziej spektakularną walką o prawa, niezależne życie i równe szanse. Owe działania aktywistów, wyrażające się w obydwu protestach, przeanalizowałam $\mathrm{w}$ perspektywie dyskursów i praktyk społecznych, poprzez które oba protesty były realizowane. Owe dyskursywne praktyki ujawniają polityczne i społeczne reakcje na niepełnosprawność wkraczającą ze sfery prywatnej do sfery publicznej, są egzemplifikacją sposobów myślenia i mówienia o obywatelu z niepełnosprawnością oraz przenoszenia wiedzy/ władzy o/nad niepełnosprawnością. Analizy przeze mnie podjęte lokują się w kulturowym modelu niepełnosprawności, który uwzględnia niepełnosprawność i normalność jako efekty generowane przez wiedzę akademicką, środki masowego przekazu i codzienne dyskursy.

Jak pisze A. Waldschmit, w każdej kulturze w danym momencie klasyfikacje te zależą od struktur władzy i sytuacji historycznej, są zależne i zdeterminowane przez hegemoniczne dyskursy. Model kulturowy uznaje niepełnosprawność nie za daną jednostkę czy fakt, ale opisuje ją jako dyskurs lub proces, doświadczenie, sytuację lub wydarzenie. Zarówno niepełnosprawność (disability), jak i sprawność (ability) odnoszą się do dominujących symbolicznych porządków i instytucjonalnych praktyk wytwarzania normalności i dewiacji, znanego i odmiennego. Zakładając konstruktywistyczny i dyskursywny charakter niepełnosprawności, można wziąć pod uwagę historyczną i kulturową perspektywę kreowania procesów włączenia i wykluczenia, stygmatyzacji jak również społeczno-kulturowe wzorce doświadczenia i tożsamości, tworzenia znaczeń i praktyk społecznych, władzy i oporu (Waldschmit 2017: 23-24). Dyskurs natomiast postrzegam jako system wiedzy, który konstruuje otaczającą nas rzeczywistośći nadaje sens wszystkiemu co nas otacza. Za M. Foucault, uznaję dyskurs za „system ludzkich wypo- 
wiedzi" i praktykę formującą przedmioty, o których dyskurs mówi, za system wiedzy, koncepcji i/lub myśli, który jest ucieleśniony w praktykach społecznych, mających dane miejsce w realnym świecie (Foucault 2000: 10).

Za Z. Melosikiem uznaję, że teoria dyskursu jest metodą analizy rzeczywistości społecznej, a dyskursy traktowane są jako społecznie skonstruowane, „systematyczne układy stosunków", w ramach których idee, twierdzenia, praktyki oraz instytucje uzyskują swoje znaczenie i swoją „rzeczywistość". My nie mówimy przez dyskursy, to dyskursy mówią poprzez nas. Tak więc dyskursy „stabilizują” nieprzerwany napływ zjawisk i wrażeń $\mathrm{w}$ „selektywnie możliwe do rozpoznania formy" Ustanawiają one założenia dotyczące oblicza, jakie rzeczywistość może przyjąć , aby „być rzeczywistością oraz determinują sposoby jej badania , także standardy prawdy i fałszu. W ten sposób dyskursy „porządkują świat” (Melosik 1994: 200). Zgodnie z koncepcją Z. Melosika uważam, że "celem dyskursywnej praktyki jest uzyskanie władzy nad znaczeniami (i zastąpienie jednych „mówców" przez innych), a każdy dyskurs uczestniczy w walce o uprawomocnienie w społeczeństwie określonych „wersji rzeczywistości” kosztem wersji alternatywnych. Takie uprawomocnienie stanowi „operację zamykania” chroni jedne interpretacje, a inne za pomocą sankcji społecznej marginalizuje i zmusza do milczenia. W ten sposób ustanawia się metanarracje, poprzez które społeczeństwo żyje, przy czym alternatywne wersje rzeczywistości są represjonowane. Alternatywne „wersje rzeczywistości" są zdeligitymizowane przez wykluczanie konstruujących je dyskursywnych praktyk (Melosik 1994: 200).

Dokonana przeze mnie krytyczna analiza dyskursów, którymi rozgrywały się protesty aktywistów z niepełnosprawnościami ujawnia owo „porządkowanie świata", owo ustanawianie metanarracji niepełnosprawności, które miały za zadanie uprawomocnić jej obowiązujące wersje i znaczenia. Krytyczna analiza owych dyskursów ukazuje jaki system przekonań i wartości wobec niepełnosprawności próbował być przez nie sankcjonowany. Krytyczna analiza dyskursu stawia sobie za cel uświadomienie ludziom, że język to nie coś naturalnego, neutralne narzędzie, ale nośnik systemu przekonań i wartości wyznawanych przez jednostki, zależny od ich pozycji i szerszych społeczno-historycznych uwarunkowań (Grzymała-Kazłowska 2004: 26). A jak zauważa J. Butler, język posiada moc formatywną i swoistą władzę poprzedzającą jakikolwiek podmiot mówiący. Wkroczenie w język to bycie nazwanym (Butler 2011: 10). Krytyczna analiza dyskursu zawiera element szczegółowej analizy tekstu, przy czym „tekst” rozumiany jest jako interakcje mówione, "multimodalne" teksty telewizji i Internetu, teksty pisane i publikowane (Duszak, Fairclough 2008: 18). Badając dyskursy, którymi realizowały się oba protesty sięgnęłam do źródeł Internetowych, które zawierały archiwa prasowe czy medialne reportaże dokumentujące ich przebieg. W ramach krytycznej analizy dyskursu posłużyłam się jakościową analizą treści, aby wyeks- 
ponować sieci znaczeń niepełnosprawności konstruowane w dyskursie polityków, aktywistów i dyskursie społecznym.

\section{Ruch społeczny Rodzice Osób Niepełnosprawnych (RON). Siła protestów, opresja władzy i społeczny opór}

W 2014 roku rodzice dzieci z niepełnosprawnością po raz pierwszy powiedzieli: dość! Sfrustrowani niemożnością zwrócenia uwagi decydentów politycznych na swoje problemy, postanowili wykorzystać najbardziej spektakularną formę sankcji ruchów społecznych- okupację „serca” polskiej demokracji Sejm RP. Unaocznili swoją obecność w miejscu, w którym się jej nie dostrzega. Sejm, jak pisze D. Kosiński, jest przestrzenią szczególnie nacechowaną symbolicznie jako materializacja demokracji przedstawicielskiej. Sam w sobie Sejm jest przedstawieniem, w idealnej wersji złożonym z wszystkich liczących się sił i części tworzących społeczeństwo (Kosiński 2018: 74). W roku 2018 ci sami rodzice, tym razem ze swoimi dorosłymi dziećmi z niepełnosprawnością, po raz drugi powiedzieli: dość! Aby zwrócić uwagę na potrzeby dorosłych osób z niepełnosprawnościami po raz drugi, mobilizując siły ruchu społecznego Rodzice Osób z Niepełnosprawnością (RON), prowadzili strajk okupacyjny Sejmu RP. Protest 2018 roku był największym w dziejach współczesnej Polski aktem walki o prawa człowieka osób niepełnosprawnych. Obie te akcje były przejawem najbardziej spektakularnej walki aktywistów z niepełnosprawnościami, ich rodziców i przyjaciół środowisk osób niepełnosprawnych. Obie te akcje będące swoistym obywatelskim nieposłuszeństwem, były przejawem działań ruchu społecznego osób niepełnosprawnych i aktywizmu osób niepełnosprawnych. Protesty stały się nową formą politycznego działania aktywistów z niepełnosprawnością. Spowodowały pojawienie się na publicznej scenie nowych aktorów domagających się prawa do posiadania praw. Protesty uruchomiły cały szereg politycznych i społecznych reakcji i wystawily polskie społeczeństwo i polskie państwo na próbę.

Zacznę od przypomnienia genezy obu protestów, które doprowadziły do powstania inicjatywy/ ruchu społecznego RON i mobilizacji środowisk osób niepełnosprawnych doprowadzających do strajku okupacyjnego Sejmu RP. Z powodu niedostatecznego wsparcia rodzin, które wychowują niepełnosprawne dziecko (m.in. brak asystentów osób niepełnosprawnych) wielu rodziców (głównie matki), aby opiekować się dzieckiem, rezygnuje z pracy w momencie jego narodzenia. Od Państwa otrzymują "ekwiwalent” - comiesięczne świadczenie pielęgnacyjne, które w 2014 roku wynosiło 620 zł. Rodzice od lat postulowali o podniesienie tego świadczenia, ale również próbowali wywalczyć wprowadze- 
nie do systemu wsparcia asystentów osób niepełnosprawnych oraz uzawodowienia swojej „domowej aktywności opiekuńczej”. Po zakończeniu edukacji tylko mały procent osób ze znaczną niepełnosprawnością ma szansę na podjęcie pracy. Otrzymują one od państwa wsparcie finansowe- rentę socjalną w wysokości 900 zł.

W 2014 roku, rodzice dzieci niepełnosprawnych rozpoczęli pierwszy okupacyjny protest Sejmu RP, z postulatem zwiększenia owego świadczenia pielęgnacyjnego. Przez 17 dni toczyły się rozmowy z ówczesnym rządem i premierem Donaldem Tuskiem. Protest 2014 roku był pierwszym medialnym performansem na scenie Sejmu RP, pierwszą tego typu bojową manifestacją, pierwszym do tej pory niespotykanym aktem aktywizmu bojowników niepełnosprawności. Jak zauważa D. Kosiński, protestujący rodzice osób z niepełnosprawnościami to grupa niewielka, ale stworzyła przedstawienie niezwykle skuteczne, lokując się wewnątrz najbardziej reprezentatywnej sceny- Sejmu, którego reprezentacyjność właśnie zakwestionowała samą swoją obecnością, podważając tym samym podstawy jego funkcjonowania (...). Bez ich fizycznej obecności Sejm ich nie reprezentuje, a Sejm, który nie reprezentuje wszystkich obywateli traci swoją rację istnienia (Kosiński 2018: 74).

W dyskursie liderów protestu głównymi znaczeniami były: wykluczenie, bieda, eutanazja w białych rękawiczkach. Jak mówili: w żadnym kraju Unii Europejskiej nie dochodzi do takiego skandalu jak tutaj, bo żaden premier, żadnego rządu nie doprowadziłby do sytuacji, gdzie rodzice z niepełnosprawnymi dziećmi wychodzą na ulicę. Państwo polskie wykonuje na naszych dzieciach eutanazję w białych rękawiczkach. Fundowane są nam głodowe świadczenia. Protest trwał 17 dni. Ówczesny rząd musiał zmierzyć się z zarzutami wykluczania rodziców i dzieci z niepełnosprawnością, z zarzutami fatalnej polityki społecznej i skazywania tych najsłabszych obywateli na życie w nędzy. Jak mówili protestujący:

„Moje dziecko tak samo zdecydowało, że chce protestować dla godnego życia wszystkich dzieci, a nawet tych, które się jeszcze nie urodziły. Czy Pan sobie zdaje sprawę, że takim dzieciom i ich rodzinom trzeba pomóc? Że kłamstwo nie doprowadza do niczego? Pan kłamie, obiecując naszym dzieciom poprawę bytu w jakimś tam roku... 2020... Panie premierze! Proszę bardzo, niech Pan teraz wstanie i zawiąże mojej córce żołądek. Bo ja do tego czasu co pan proponuje nie jestem w stanie ani wyżywić mojego dziecka, a tym bardziej go rehabilitować, ani leczyć. Jest Pan kłamcą, bo nam Pan obiecał, w styczniu nam Pan obiecał, że za dwa tygodnie będziemy wszystko mieć i co i nic nie ma. Wszyscy kłamiecie. To jest zbrodnia. Nie wyjdę stąd dopóki nie będzie ustawy, nawet jakbym miała tu skonać"1.

„Rodzic dzieci niepełnosprawnych jest pozostawiony sam sobie. Dlaczego! Czy rząd i politycy są bogami? Do cholery oni są naszymi pracownikami! Bo jakby nie było to my im płacimy z naszych podatków. Tłumaczą się dziurą w budżecie, chwila moment na

1 https://www.youtube.com/watch?v=SSmewuwCtJU [dostęp: 25.09.2019]. 
nagrody dla siebie mają? Dlaczego moje dziecko dostaje 153 zł? Moje dziecko cierpi, od urodzenia. Dlaczego nie chcą inwestować w nasze dzieci?"2.

Politycy ówczesnej opozycji, stojący murem za protestującymi przynosili kanapki, zagrzewali do walki i „wyrywania z gardła władzy” tego co osobom niepełnosprawnym się należy, zapewniali, że jeżeli oni będą rządzić to żadna osoba niepełnosprawna nie będzie wykluczana. Jak obiecywał protestującym Jarosław Kaczyński:

„Szanowni Państwo w piątek rozmawiałem z Paniami i Panami, którzy tutaj protestują w sprawie wsparcia państwa dla opiekunów dzieci niepełnosprawnych, wczoraj przedstawiciele naszej partii przedstawili, przekazali projekt ustawy, która by rozwiązywała te problemy, chciałem bardzo mocno podkreślić, że będziemy wykorzystywali wszystkie możliwości po to aby skłonić rząd Donalda Tuska i samego premiera, aby rozwiązać te niezwykle istotne i niezwykle palące z punktu widzenia rodziców dzieci niepełnosprawnych problemy, ale także niezwykle ważne moralnie kwestie. To jest taka sprawa, która jest swojego rodzaju wskaźnikiem, wykładnikiem działania państwa, działania państwa tam, gdzie kwestie moralne, kwestie zobowiązań wobec tych, którzy zostali potraktowani przez los szczególnie okrutnie, pokazują jakie to Państwo jest, jaka ta władza jest. Jeżeli ta władza nie jest $w$ stanie wykazać empatii, nie jest w stanie wykazać współczucia, to pokazuje swoją twarz"3.

Po 17 dniach protest został zawieszony, rodzice wywalczyli wzrost świadczenia pielęgnacyjnego, które stopniowo wzrastało i dziś jest to kwota ok. 1400 zł.

W kwietniu 2018 roku rozpoczął się drugi, najbardziej dramatyczny i najdłuższy akt obywatelskiego nieposłuszeństwa aktywistów z niepełnosprawnością i ich rodziców. Tym razem walka toczyła się o zrównanie kwoty renty socjalnej z najniższą rentą z ZUS z tytułu całkowitej niezdolności do pracy wraz ze stopniowym podwyższaniem tej kwoty do równości minimum socjalnego obliczonego dla gospodarstwa domowego z osobą niepełnosprawną oraz o comiesięczny dodatek rehabilitacyjny w wysokości 500 zł. W swoich postulatach aktywiści żądali, od obecnego rządu, podjęcia niezwłocznych działań legislacyjnych ułatwiających osobom z niepełnosprawnością godne i samodzielne życie. Osoby z niepełnosprawnością i ich rodzice liczyli na to, że otrzymają wsparcie wraz ze zmianą władzy w 2015 roku. Jak mówiła liderka Iwona Hartwich:

„Powstają kolejne zespoły, a z ich pracy nic nie wynika. Nie mamy już pieniędzy, żeby jeździć na kolejne spotkania. Dlatego postanowiliśmy odwiesić protest. Dziś jesteśmy głosem dorosłych dzieci niepełnosprawnych, których poziom życia pogarsza się wraz z wiekiem. To są jedyne środki na utrzymanie. To głodowe świadczenie" ${ }^{\prime \prime}$.

\footnotetext{
https://www.youtube.com/watch?v=Rf9wXrQA3XM [dostęp: 25.09. 2019].

https://www.youtube.com/watch?v=UvzqB2FGLPQ [dostęp: 25.09. 2019].

$4 \mathrm{http} / / /$ pressmania.pl/rozpoczal-sie-kolejny-protest-rodzicow-dzieci-niepelnosprawnych-w-sejmie/ [dostęp: 25.09.2019].
} 
Obecny rząd, obecna władza, która w swoich postulatach „z troską pochyla się nad każdym niepełnosprawnym" musiała zmierzyć się z ich słowami, obrazami oraz emocjami. Spektakl rozgrywający się ponownie na scenie Sejmu RP trwał 40 dni i objawił całej Polsce nie tylko sytuację życiową osób z niepełnosprawnością, ale obnażył również hipokryzję i opresję władzy oraz nasz, społeczny stosunek do niepełnosprawnych obywateli.

Jakimi dyskursami i praktykami społecznymi realizował się ten protest? $\mathrm{Na}$ pierwszy plan wysuwają się trzy towarzyszące protestowi dyskursy: polityczny, aktywistów i dyskurs społeczeństwa. $\mathrm{W}$ dyskursie aktywistów ponownie pojawiają się kwestie życia w nędzy, nierównych szans, braku dialogu i wykluczenia. Tym razem liderzy protestu mówili tak: od wielu lat nikt nie wsłuchuje się w głos rodziców i opiekunów dorosłych osób niepełnosprawnych. Państwo polskie skazuje dorosłych ze znaczną niepełnosprawnością na niebyt, na życie w nędzy. Protestujący aktywista z niepełnosprawnością, Jakub Hartwich mówił:

„Wie Pan co jest smutne? Że trzeba się do takich radykalnych sposobów odnieść, żeby tu nas społeczeństwo mogło usłyszeć" ${ }^{\prime 5}$.

Protestujący po raz kolejny unaocznili swoją obecność, zajęli korytarze sejmowe i domagali się spotkania z obecnym rządem, politykami, którzy w 2014 roku byli w opozycji i obiecywali wtedy poprawę sytuacji osób niepełnosprawnych. Cała Polska była świadkiem tych rozmów, słów i emocji. Aktywiści uparcie powtarzając słowa: wstyd, bieda, wykluczenie walczyli o spełnienie swoich dwóch postulatów.

Dyskurs polityków, dzięki któremu próbowano odzyskać kontrolę nad Sejmem i protestem składał się z wielu wypowiedzi polityków partii rządzącej, wielu znaczeń, które to w jakiś sposób próbowały uchwycić istotę dziejącej się akcji protestacyjnej oraz istotę samej niepełnosprawności. Odzyskiwanie kontroli nad Sejmem i protestem rozegrało się przy użyciu medycznego i moralnego dyskursu. Po pierwsze, politycy odwołali się do stereotypowego przekonania, że osoby z niepełnosprawnością nigdy nie wychodzą z okresu dzieciństwa. Dorosłych aktywistów z niepełnosprawnością zdefiniowano jako dzieci, aby potem w ramach tego dyskursywnego mechanizmu odebrać im sprawczość i autorstwo działań. Na owej definicji „dziecka z niepełnosprawnoscią" politycy partii rządzącej oparli oceny moralne skierowane wobec rodziców. Niegodnych rodziców, którzy przetrzymują w Sejmie te „biedne, niepełnosprawne dzieci”. Ponadto, $w$ opiniach polityków, uczynienie niepełnosprawności tematem publicznej debaty jest niegodne. Jacek Żalek mówił następująco: 
„Traktują dzieci jak żywe tarcze. Nie można dać im tej gotówki. Jeżeli na oczach całej Polski można traktować dzieci jak zakładnika do swoich interesów, to boję się, że w zaciszu domów może być niestety tak samo"6.

Bernadetta Krynicka, „moim zdaniem to jest karygodne, że ci rodzice przetrzymują niepełnosprawne osoby w Sejmie tyle dni. Znalazłabym paragraf na tych rodziców, którzy przetrzymują swoje dzieci w Sejmie w takich warunkach- niegodnych"7.

Po drugie, politycy z ogromną troską, zainteresowali się "niepełnosprawnym ciałem narażonym na choroby". Dyskurs medyczny, poprzez który zazwyczaj interpretowana jest niepełnosprawność objawił się znaczeniami: chorego i słabego ciała oraz „zagrożenia epidemiologicznego”. Jak mówił Marszałek Senatu, Stanisław Karczewski:

„Osoby niepełnosprawne są bardziej narażone, u osób niepełnosprawnych występują również inne choroby, ryzyko występowania jakiejkolwiek choroby jest dużo większe. Spanie na podłodze nie jest komfortowe, ani zdrowe. I powiedziałem to z pełną troską o te osoby! Ubolewam z powodu tego protestu w Sejmie, to jest niepotrzebne. To nie jest miejsce do prowadzenia dialogu. Obóz rządzący "jest wrażliwy" i wie, że „są problemy, które wymagają przeanalizowania”. Czy ci ludzie nie widzą tych dzieci, które tam są, które nie mogą się wykąpać, wyjść na dwór? Ja to widzę i ubolewam nad tym. Żal mi jest tych dzieci, że te dzieci nie mogą normalnie wyjść na zewnątrz i zobaczyć jak pięknie wygląda wiosna. Źle, że wykorzystuje się dzieci do tego protestu"8.

Dyskurs ten jest swoistą biopolityczną technologią władzy nad ciałem, która utrwala wizerunek osób niepełnosprawnych jako słabych, które z powodu ucieleśnionych ograniczeń nie mogą same o sobie decydować. To konstruowanie dominującego normocentrycznego porządku społecznego i narzucanie poprzez symbole i język swojego obrazu świata niepełnosprawności. Do cielesności osób niepełnosprawnych odniosła się również inna posłanka obozu rządzącego komentując: na antresoli, w miejscu dla prasy i w korytarzu głównym na parterze panuje trudny do zniesienia smród 9 .

Dyskursy polityków pacyfikujących protest realizował się ponadto w różnorodnych mechanizmach kontroli, opresji i dyskryminacji, w konkretnych społecznych praktykach wykluczania takich jak: zamkniecie Sejmu dla odwiedzających, zakaz otwierania okien, spacery tylko dla osób z niepełnosprawnością, ogranicze-

6 http://www.tokfm.pl/Tokfm/7,102433,23368475,zalek-ostro-o-rodzicach-w-sejmie-nie-mozna-im-dacgotowki.html [dostęp:, 25.06.2019].

$7 \mathrm{https}: / /$ wiadomosci.onet.pl/kraj/krynicka-o-protestujacych-niepelnosprawnych-to-nie-sa-dla-mniepartnerzy-do-rozmowy/581g49f [dostęp: 25.06.2019].

8 https://wpolityce.pl/polityka/395181-karczewski-o-protescie-niepelnosprawnych-w-sejmie-sa-osoby-ktore-przebywaja-dlugo-w-jednym-miejscu-i-jest-zagrozenie-epidemiologiczne [dostęp: 25.09.2019].

9 https:/www.se.pl/wiadomosci/polityka/pawlowicz-chamsko-uderza-w-protestujacych-niepelnosprawnych-aa-hmhT- eibr-jpzm.html [dostęp: 25.09.2019]. 
nie korzystania z łazienek, spanie przy zapalonym świetle, ograniczanie przestrzeni - ustawianie barierek, oddzielanie protestujących zasłonami oraz straszenie wystawieniem rachunku za protest. Jak mówił marszałek Sejmu Marek Kuchciński:

„To są także koszty, proszę państwa, bo codzienne wyżywienie kosztuje, i tak dalej. Bierzemy to na siebie, ale będziemy musieli zastanowić się, czy ktoś musi za to zapłacić10.

Inną opresyjną praktyką pacyfikującą protest była dezinformacja. Opinii publicznej przestawiano zawyżone dane na temat wsparcia finansowego, które otrzymują osoby niepełnosprawne od państwa, mówiono, że w sejmie protestuje grupka osób niepełnosprawnych, która nie ma poparcia w szerokim środowisku osób niepełnosprawnych. Po kilku dniach negocjacji rząd wyraził zgodę na spełnienie postulatu: podniesienia renty socjalnej. Na drugi postulat, rząd nie chciał się zgodzić. Zamiast dodatku rehabilitacyjnego w wysokości 500 zł, zaproponowano różne ulgi w zaopatrzeniu w wyroby medyczne i zniesienie ograniczeń dotyczących liczby wydawanych wyrobów medycznych. Osoby z niepełnosprawnością mogłyby też korzystać ze świadczeń specjalistycznych bez konieczności uzyskania skierowania i zwykłej kolejki. Rząd „wycenił” swoją ofertę na 520 zł miesięcznie. Uznano negocjacje za skończone. Opinia publiczna bombardowana była informacjami, że rząd spełnił wszystkie oczekiwania protestujących i dalszy protest jest zupełnie niepotrzebny. Jak mówił Jacek Sasin:

„Te oczekiwania, które zostały sformułowane na początku protestu zostały spełnione. Protest jest niepotrzebny, nie wiadomo o co w ogóle chodzi protestującym"11.

Protest osób niepełnosprawnych był również testem dla polskiego społeczeństwa, które obserwując ów czterdziestodniowy spektakl, podzieliło się w swoich poglądach. Można było zaobserwować polaryzację społecznych reakcji. Część Polaków popierała walkę aktywistów o swoje prawa, dostrzegała niesprawiedliwość państwa polskiego oraz praktyki wykluczania tej, jednak najsłabszej, grupy społecznej. Inna część społeczeństwa uznała, że niepełnosprawni otrzymują od państwa bardzo duże wsparcie materialne, zarzucała protestującym matkom za dobry wygląd, a protestującym aktywistom z niepełnosprawnością posiadanie zbyt drogich butów, co miało świadczyć o ich świetnej kondycji finansowej i próbach wyłudzania pieniędzy. W dyskursie społecznym towarzyszącym protestowi pojawiają się sprzeczne znaczenia: m.in. wstyd za Polskę, dzielni ludzie, ale i obrzydliwość, terroryści z niepełnosprawnością. Jak można było przeczytać w społecznych komentarzach:

\footnotetext{
${ }^{10}$ https://www.tvn24.pl/wiadomosci-z-kraju,3/sejm-wystawi-rachunek-za-koszty-protestu-osob-niepelnosprawnych, 841693.html [dostęp: 25.09.2019].

11 https://natemat.pl/238971, protest-rodzicow-osob-niepelnosprawnych-sasin- rzad-spelnil-postulaty [dostęp: 25.09.2015].
} 
„Wstyd mi za Polskę"12

„Niegodziwe jest zachowanie niepełnosprawnych terrorystów, już dostali „swoje”. Terroryści chcieli więcej!"13

„Ci co plują tutaj, na te dzielne osoby niepełnosprawne, wkrótce sami się przekonają jak to jest być krzywdzonym i poniewieranym przez bezduszną i bezwzględną władzę, dla której człowiek jest tylko wyborczym głosem, a później tylko jej śmierdzi i przeszkadza"14.

„Uważam za skandal, że wykorzystywane są osoby niepełnosprawne. Hańbą dla tychże rodziców jest obleganie Sejmu, czy nie mają krzty honoru???"15

Po czterdziestu dniach protest zostaje zawieszony. Niepełnosprawni opuszczają Sejm, otrzymując zakaz wstępu do niego do 2020 roku. Wywalczyli podniesienie kwoty renty socjalnej o ok 165 zł.

Społeczny krajobraz po rewolucji, której nigdy nie było. Co z aktywizmem osób niepełnosprawnych?

Protesty osób niepełnosprawnych i ich rodziców, które miały miejsce w 2014 i 2018 roku były największymi akcjami aktywistów oraz największymi akcjami ruchu społecznego osób niepełnosprawnych w Polsce. Zdesperowani, porzuceni przez władzę i system, w poczuciu bycia niewysłuchanym i marginalizowanym postanowili zażądać spełnienia praw zapisanych m.in. w Konwencji Praw osób Niepełnosprawnych ONZ. Realizując największą sankcję ruchów społecznych jaką jest protest okupacyjny stanęli na scenie sejmu RP, na której unaoczniając swoją obecność, wykluczanych obywateli drugiej kategorii, powiedzieli; dość! Ich protest stał się, przez czterdzieści dni jego trwania, głównym medialnym tematem. Temat niepełnosprawności, rzadko omawiany w mediach, teraz stał się tematem ważnym. Te 40 dni spektaklu rozgrywającego się na scenie sejmowej przyniosło obserwującemu je polskiemu społeczeństwu wiedzę na temat realnego życia osób z niepełnosprawnością. Aktywiści z niepełnosprawnością, pomimo połowicznego zwycięstwa protestu, oceniają tę akcję pozytywnie. Jak mówią:

„Przez 40 dni w sejmie zmieniliśmy świadomość na temat niepełnosprawności. Przez ten protest pokazaliśmy, że nasze prawa były, są i będą" (Glinka 2018).

\footnotetext{
12 http://wyborcza.pl/7,75398,23458841,iwona-hartwich-w-rmf-fm-protest-moze- zostac-zawieszony. html [dostęp: 25.09.2019].

13 Tamże.

14 Tamże.

15 https://dorzeczy.pl/kraj/62107/W-Sejmie-trwa-protest-rodzicow-osob-niepelnosprawnych.html [dostęp: 25.09.2019].
} 
„Proponowane przez rząd rozwiązania nie zaspokajają potrzeb osób niepełnosprawnych. Nie jesteśmy słuchani, co powoduje, że ten ruch społeczny się rodzi. On się rodzi z buntu, bunt i złość jest w nas. Ruchu na rzecz osób z niepełnosprawnościami w Polsce nie ma, ale on się rodzi, myślę, że powstanie" (Żeglicka 2018).

„Protest pokazał ideę przewodnią Konwencji ONZ, czyli to, że osoby z niepełnosprawnościami nie są biernymi odbiorcami pomocy, tylko aktywnymi obywatelami, którym należą się takie same prawa jak każdemu innemu" (Jagura 2018).

Protest obnażył paternalizm władzy, która pod maską altruistycznej życzliwości i etyki troski skrywała paternalistyczną dominację. Odzyskanie panowania nad Sejmem i pacyfikacja protestu obyła się poprzez dyskurs medyczny, który to zamknął aktywistów w definicjach słabego i chorego ciała, odbierając im moc sprawczą. Dyskurs „wiecznego dziecka” miał na celu napiętnować niegodnych rodziców, przenoszących osobiste doświadczenia do strefy publicznej, wykorzystujących swoje „biedne niepełnosprawne dzieci”, ale również owo zdefiniowanie dorosłych aktywistów z niepełnosprawnością jako dzieci miało im odebrać możliwość mówienia we własnym imieniu oraz odebrać głos w debacie. Polityczne praktyki dyskursywne zmuszają osoby z niepełnosprawnością do milczenia, odbierają im sprawczość i głos. Dyskursywne praktyki władzy delegitymizują alternatywne „wersje rzeczywistości” osób niepełnosprawnych i pod płaszczykiem etyki troski spychają niepełnosprawnych na margines życia społecznego. Można powiedzieć o dyskursywnej „operacji zamykania” w znaczeniach. Niepełnosprawni takim dyskursywnym praktykom i sankcjonowanym przez nie porządkom społecznym mówią - NIE! Protesty z 2014 i 2018 roku nie były rewolucją, ale zapoczątkowały ruch społeczny osób z niepełnosprawnością. Dziś po ponad roku od tamtych akcji można mówić o mobilizacji w Polsce ruchu społecznego wokół problemu niepełnosprawności. W 2019 roku aktywiści z niepełnosprawnością mobilizowali się na protesty jeszcze dwa razy. W maju i wrześniu. Zbierali się przed Sejmem i kancelarią premiera, aby wyrazić swoje niezadowolenie $z$ realizacji przez rząd obietnic, które zostały poczynione podczas protestu.

Hasło „Nic o nas bez nas” stało się hasłem przewodnim środowisk osób niepełnosprawnych, działają organizacje self-adwokatów, powstała inicjatywa "Chcemy całego życia” monitorująca sposoby wdrażania w życie praw Konwencji Osób Niepełnosprawnych. We wrześniu 2019 odbył się w Warszawie pierwszy Kongres Kobiet z Niepełnosprawnościami, a w październiku odbędzie się piąty Kongres Osób Niepełnosprawnych, z tegoroczną myślą przewodnią „Aktywni obywatele i Aktywne obywatelki". Ta samoorganizacja osób niepełnosprawnych i to bezpośrednie działanie jest wyzwaniem dla dominujących stereotypów bezsilności i uprzedmiotowienia, dla dyskursywnych praktyk zmuszających do milczenia i powodujących wkluczenie. Główne wartości ruchu osób niepełnosprawnych, jak zauważa T. Shakespeare to samodzielność, integracja i niezależność, 
a samoorganizacja stanowi wyzwanie wobec mitu o bierności osób niepełnosprawnych (Shakespeare 2018: 50-51). Warto również dodać, że we wrześniu 2018 roku w Genewie, Komitet ONZ rozpatrywał, jak nasze państwo realizuje Konwencję Praw Osób niepełnosprawnych. Po raz pierwszy od jej ratyfikowania przez Polskę w 2012 roku. Komitet ONZ wydając rekomendacje dla polskiej polityki niepełnosprawności, w całości uwzględnił postulaty polskich aktywistów.

Działalność ruchów społecznych osób niepełnosprawnych, aktywizm osób niepełnosprawnych jest wyrazem ich krytycznej oceny własnej sytuacji, wyrazem niezadowolenia, żądaniem zmiany i uznaniem, że prawa człowieka są także prawami osób niepełnosprawnych. Aktywizm osób niepełnosprawnych jest przejawem ich dążeń emancypacyjnych, przezwyciężeniem relacji wyzysku, nierówności i ucisku. To dążenie ku polityce życia, której głównym celem jest uzyskanie odpowiedniego poziomu autonomii i samorealizacji (Giddens 2012). Ich "obywatelskie nieposłuszeństwo" jest wypowiedzią i aktem wobec zastanej wypowiedzi społeczno/politycznej, jest próbą przełamania obowiązującej narracji wobec niepełnosprawności i przez to staje się tym, co wytwarza lub rozszerza wielość. Ich działanie jest także wypowiedzią grupy mającą za cel zamanifestowanie a następnie wytworzenie pewnej jedności w postaci m.in. nowego, powszechnie obowiązującego prawa.

Nieposłuszeństwo obywatelskie aktywistów z niepełnosprawnością jest zatem aktem opartym na fenomenie wzajemności, definiującym ich jako współobywateli. Aktywizm osób niepełnosprawnych można by postrzegać za J. Ranciere jako "grę w/o emancypację" (Ranciere 2008: 105). Dla J. Ranciere'a polityczne jest miejscem styku dwóch heterogenicznych procesów. Pierwszy z nich dotyczy rządzenia. Polega na organizowaniu we wspólnotę ludzkiego zgromadzenia za jego własnym przyzwoleniem i opiera się na hierarchicznym podziale miejsc i funkcji. Ten proces nazwę policją. Drugi z nich to równość. Polega on na grze praktyk zakładających równość każdego z każdym i troskę o jej weryfikację. Nazwa, która najtrafniej opisuje tę grę to emancypacja (...) Każda policja wyrządza krzywdę równości. Polityczne to scena, na której weryfikacja równości powinna przybrać formę leczenia krzywdy (Ranciere 2008: 105-106). Teoria polityki Ranciere'a, jak analizuje ją Szkudlarek, jest budowana na bazie koncepcji „dzielenia postrzegalnego", to znaczy estetycznych reżymów postrzegania rzeczywistości operujących granicami widzialności, słyszalności i sensowności, które tworzą ramy świata wspólnego. To, co te ramy stabilizuje, nazywa Ranciere mianem policji, a to, co je przemieszcza - to polityka sensu stricto. Edukacja odgrywa w tych procesach niezwykle istotną rolę zarówno w wymiarze "policyjnego" stabilizowania granic postrzegania rzeczywistości, jak i ich "politycznego” przemieszczania. Emancypacja jest w tym kontekście aktem niezgody (dissensus), działaniem „nie na miejs$\mathrm{cu}^{\prime \prime}$ i mówieniem „nie w tym czasie”, demonstracją obecności tam, gdzie miało nas 
nie być, i manifestacją zdolności w zakresie kompetencji, które z założenia nam nie przysługują (Szkudlarek 2013: 69). W tej perspektywie aktywizm osób niepełnosprawnych można postrzegać jako proces weryfikacji równości i formę leczenia krzywd, jako emancypacyjny akt niezgody.

\section{Bibliografia}

Arendt H. (2005), Polityka jako obietnica, przeł. W. Madej i M. Godyń, Prószyński i S-ka, Warszawa.

Arendt H. (1999), Niepostuszeństwo obywatelskie, przeł. W. Madej, Aletheia, Warszawa.

Bogaczyk-Vormayr M. (2013), W kwestii niepostuszeństwa obywatelskiego, Filo-Sofija, nr 23 vol. 4.

Butler J. (2010), Walczące stowa. Mowa nienawiśsi i polityka performatywna, przeł. A. Ostolski. Wydawnictwo Krytyka Polityczna. Warszawa.

Bynoe I., Oliver M., Barnes C. (1991), Equal Rights for Disabled People, IPPR, Londyn.

Fairclough N. (2004), Analyzing Discourse, Textual Analysis for Social Research, LondonNew York.

Fairclough N., Duszak A. (2008), Krytyczna analiza dyskursu, Universitas, Kraków.

Foucault M. (2000), Archeologia wiedzy, przeł. A. Siemek, PIW, Warszawa.

Giddens A. (2005), Socjologia, PWN, Warszawa.

Giddens A. (2012), Nowoczesność i tożsamość, PWN, Warszawa.

Grzymała-Kazłowska A. (2004), Socjologicznie zorientowana analiza dyskursu na tle wspótczesnych badań nad dyskursem, Kultura i Społeczeństwo, nr 1.

Kosiński D. (2018), Odzyskiwanie obecności [w:] E. Godlewska-Byliniak, J. Lipko-Konieczna (red.), Niepetnosprawność i społeczeństwo. Performatywna sita protestu, Wydawnictwo Biennale - Fundacja Teatr 21, Warszawa.

Melosik Z. (1994), Poststrukturalizm i spoteczeństwo (refleksje nad teoriq M. Foucaulta) [w:] J. Brzeziński, L. Witkowski (red.), Edukacja wobec zmiany społecznej, Poznań-Torun.

Oddawanie gtosu: o prawach i proteście osób z niepetnosprawnościami. Rozmowa z Adrianem Glinka, Karolina Hammer, Jarosławem Jaguara, Agnieszka Król, Katarzyna Żeglicka, prowadzita Natalia Kowalska [w:] E. Godlewska-Byliniak, J. Lipko-Konieczna (red.), Niepetnosprawność i społeczeństwo. Performatywna siła protestu, Wydawnictwo Biennale - Fundacja Teatr 21, Warszawa.

Ranciere J. (2008), Na brzegach politycznego, przeł. I. Bojadżijewa, J. Sowa, Ha!art, Kraków. Scott A. (1990), Ideology and New Social Movements, Unwin Hyman, Londyn.

Shakespeare T. (2018), Samoorganizacja osób niepetnosprawnych. Nowy ruch spoteczny? [w:] E. Godlewska-Byliniak, J. Lipko-Konieczna (red.), Niepetnosprawność i społeczeństwo. Performatywna sita protestu, Wydawnictwo Biennale-Fundacja Teatr 21, Warszawa.

Stoczewska B. (2017), Jeszcze raz o obywatelskim nieposłuszeństwie - interpretacje, spory wokót pojęcia, Krakowskie Studia Międzynarodowe, nr 3.

Szkudlarek T. (2015), Różnice, równość i edukacja: polityka inkluzji i ignorancja [w:] T. Szkudlarek, A. Komorowska-Zielony (red.), Różnice, edukacja, inkluzja, Wydawnictwo UG, Gdańsk.

Waldschmit A. (2017), Disability Goes Cultural [w:] A. Waldschmit, H. Berressem, M. Ingwersem (red.), Culture - Disability - Theory, Bielefeld. 